\title{
The moderating influence of involvement with ICTs in mobile services
}

\section{La influencia moderadora de la implicación con las TICs en los servicios móviles}

\author{
Cristina Calvo-Porral and Manuel Nieto-Mengotti \\ Business Administration Department, Facultad de Economia y Empresa \\ Universidade da Coruna, A Coruna, Galicia, Spain
}

\begin{abstract}
Purpose - The growing availability of wireless internet services and the great popularization of smartphones and other mobile devices means a greater challenge for mobile service companies that need to identify the factors influencing the use behavior of mobile services. So considering that the level of consumer involvement can lead to differences in service outcome evaluations, this study aims to examine whether consumer involvement with information and communication technologies (ICTs) has a moderating influence on consumer behavior in mobile services

Design/methodology/approach - The authors propose an integrative model of the usage of mobile services to examine the moderating role of involvement with ICTs. Drawing on a sample of 493 users, two levels of involvement with ICTs were examined; and data were analyzed through multiple-group structural equation modeling.

Findings - Findings show that the level of consumer involvement with ICTs influences the behavior in the mobile services. Further, the findings support that mobile services' perceived quality, followed by the service perceived value are the factors with a stronger influence in satisfaction with mobile services, regardless the level of consumer involvement with ICTs. However, the mobile company corporate image has a lower influence. In addition, the results support the partial moderating role of involvement with ICTs in the loyalty toward mobile service providers, suggesting that consumers lowly involved with ICTs experience a greater impact of the service quality on their loyalty.

Originality/value - The main contribution of this study is the examination of the influence of involvement with technologies in consumer behavior in the mobile services
\end{abstract}

Keyword Mobile services, Involvement, Information and Communication Technologies (ICTs), Consumer behavior

Paper type Research paper

(C) Cristina Calvo-Porral and Manuel Nieto-Mengotti. Published in Spanish Journal of Marketing ESIC. Published by Emerald Publishing Limited. This article is published under the Creative Commons Attribution (CC BY 4.0) licence. Anyone may reproduce, distribute, translate and create derivative works of this article (for both commercial and non-commercial purposes), subject to full attribution to the original publication and authors. The full terms of this licence may be seen at http:// creativecommons.org/licences/by/4.0/legalcode
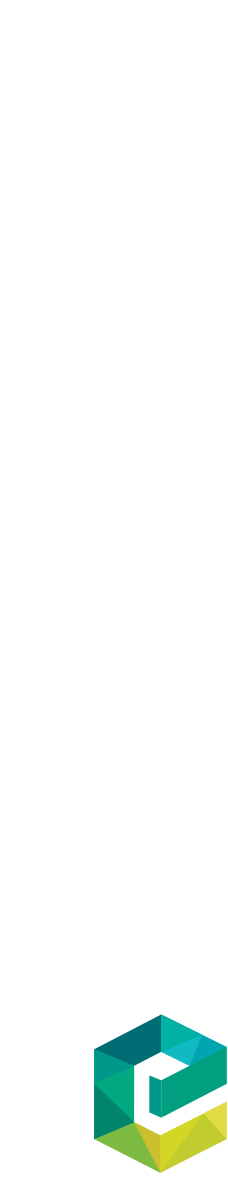


\section{Resumen}

Propósito - La disponibilidad creciente de los servicios internet inalámbrico y la gran popularización y adopción de los smartphones y de otros dispositivos móviles supone un gran desafío para las compañías de servicios móviles que necesitan identificar aquellos factores que influyen en el comportamiento de uso de los servicios móviles. Así, considerando que el nivel de implicación del consumidor puede llevar a diferencias en las evaluaciones de los resultados de los servicios, este estudio analiza si la implicación del consumidor con las tecnologías de la información y la comunicación (TICs) tiene una influencia moderadora en el comportamiento del consumidor en los servicios móviles.

Metodología - Se propone un modelo integrador sobre el uso de los servicios móviles para examinar el rol moderador de la implicación del consumidor con las TICs. Sobre la base de una muestra de 493 usuarios, se analizaron dos niveles de implicación con las TICs; y los datos fueron analizados mediante un modelo multigrupo de ecuaciones estructurales.

Resultados - Los resultados muestran que el nivel de implicación del consumidor con las TIC influye en su comportamiento hacia los servicios móviles. Además, nuestros resultados respaldan que la calidad percibida de los servicios móviles, seguida del valor percibido de estos servicios son los factores con mayor influencia en la satisfacción con los servicios móviles, independientemente del nivel de implicación del consumidor con las TIC. Sin embargo, la imagen corporativa de la compañía de servicios móviles tiene una influencia menor. Adicionalmente, nuestros resultados muestran el rol moderador parcial de la implicación con las TIC en la lealtad hacia los proveedores de servicios móviles, sugiriendo que los consumidores poco implicados con las TIC experimentan un mayor impacto de la calidad del servicio en su lealtad.

Valor - La principal contribución de este estudio es el análisis de la influencia de la implicación del consumidor con las tecnologías, en su comportamiento hacia los servicios de comunicación móvil.

Palabras clave - Servicios móviles, Implicación, Tecnologías de la Información y la Comunicación (TICs), Implicación, Comportamiento del consumidor.

Tipo de artículo - Trabajo de investigación

\section{Introduction}

The population of mobile service users runs over several million today. Likewise, the telecommunications service industry is one of the most important sectors, with revenues exceeding US\$2tn and a 4 per cent growth rate over the past five years (International Telecommunication Union, 2015). Regarding the Spanish mobile communication industry, the number of mobile subscriptions account for 51.5 million of contracts in year 2016 (Comision Nacional de los Mercados y la Competencia, 2017), being Movistar and Vodafone the mobile service providers with the highest market share.

The reason is that the growing availability of wireless internet services, the increasing demand and the popularization of the smartphones and other mobile devices have created a great market for mobile service companies. In fact, smartphones and mobile devices have become communication devices integrated into everyone's daily life (Kuo et al., 2009), being exponentially adopted by users today. In this increasingly competitive market, the mobile service providers are trying to attract new customers and retain the current ones (Kim et al., 2004), and the ability to provide a high level of user satisfaction is a key issue to differentiate mobile communication services from competitors and enhance customer loyalty (Deng et al., 2010). One critical issue for the success of mobile service providers is their capability to retain their current customers and make them loyal (Aydin and Özer, 2005; Zhou, 2011). Likewise, technology is increasing exponentially and involves many of today's products. Information and communication technologies (hereafter ICTs) became an integral part of the lives of people, improving their quality of life, being used for the fulfillment of various purposes such as entertainment, work, leisure or social relationships; similarly, mobile communication services such as mobile banking or mobile shopping are powered by the advances in ICTs.

Identifying the factors that influence the level of actual use of a technology has been perceived essential to make the adoption of a given technology more attractive (Baabdullah 
et al., 2018), and one of these factors is the level of consumer involvement. As ICTs become increasingly sophisticated, they have a greater capacity to encourage user involvement; in addition, the individual level of involvement can act as a powerful motivation toward belief

ICTs in mobile services related to ICTs, having great explanatory power in use behavior (Barnes et al., 2019).

However, considering that the consumer involvement can lead to perceived differences in service outcome evaluations, to date, the research on the user involvement with ICTs and its influence on the mobile service behavior has been scarce. The great majority of prior research on ICT mainly relates to the acceptance of ICTs and to behavioral aspects such as the computerrelated experience, emotional aspects or cognitive aspects, like computer knowledge or computer self-efficacy (Durndell and Haag, 2002). Therefore, while the acceptance toward technologies and their use has been broadly studied in previous research, there is scarce research on the potential moderating influence of consumer involvement with ICTs. In this context, and based on the heuristic-systematic information processing model proposed by Chaiken (1980), we will examine the moderating effect of the involvement level on the mobile services' context.

In the present study, we assume the term involvement with ICTs as the degree to which an individual is involved with technologies, likes and looks forward to learn about technologies. Accordingly, we propose and examine the potential moderating influence of the level of the consumer involvement with ICTs in the creation of satisfaction and loyalty with mobile communication services. Therefore, the major contribution of the present paper is the analysis as a potential moderating variable of a user-based attribute - the level of consumer involvement with ICTs - in the mobile communication service behavior.

The present article is structured as follows. First, in Section 2 we provide a literature review of the theoretical framework and the conceptual model and the research hypotheses are proposed. Then, Section 3 presents the methodology. Next, in Section 4, the results are presented and discussed. Finally, some conclusions and implications for researchers are proposed in Section 5.

\section{Conceptual framework and research hypothese}

\subsection{The use of mobile communication services}

Besides conventional mobile services that include voice and text-messaging, recent mobile services include a wide array of applications and value-added services (Wang et al., 2019), attracting customers for their applications that meet the customer needs.

Previous research shows that one of the main outputs in user behavior is satisfaction. User satisfaction could be conceptualized as an experience-based overall evaluation made by the user on whether the expectations of the services obtained from a provider have been fulfilled; or as the assessments made by the customer regarding the value drivers related to the consumption experience (Eshghi et al., 2007). In the mobile communication services context, the user satisfaction reflects the degree of an individual's positive feeling for a mobile service provider (Deng et al., 2010). Therefore, when the user has a good experience with a mobile communication service provider, he/she will develop greater levels of satisfaction (Deng et al., 2010; Wang et al., 2019). More precisely, the user satisfaction with mobile services has been related to the quality of communications, the high value for money, the customer services provided and the convenient procedures, along with the mobile provider meeting users' personal needs (Gerpott et al., 2001). Consequently, in our study, we will define customer satisfaction as the overall user perception when using mobile communication services.

2.1.1 Mobile service perceived value. Perceived value could be defined as the consumers' cognitive tradeoff between the perceived benefits of a given service and the monetary cost for using it (Venkatesh et al., 2012). Similarly, perceived value is closely related to satisfaction (Sweeney and Soutar, 2001). Other authors, such as Im et al. (2015), note that perceived value can be approached through two dimensions - utilitarian and hedonic value. More precisely, in the 
SJME

23,1

context of mobile services, the utilitarian value is closely related to the efficiency, resulting from the use of a particular service in accomplishing an everyday task, and thus, perceived value could be considered utilitarian and instrumental in nature (Li and Mao, 2015). On the other hand, hedonic perceived value could be considered as resulting from the fun and pleasure derived from the use of mobile services ( $\mathrm{Li}$ and Mao, 2015). Similarly, in the mobile services sector, recent studies consider that both components are interrelated; consequently, perceived value could be defined as a multidimensional variable derived from the consumption or usage experience (Deng et al., 2010). In this line, Kuo et al. (2009) define the mobile service perceived value as the evaluation of the benefits of the service by users, based on their advance sacrifices and ex post perceived performance when they use mobile communication services. Therefore, users integrate their perceptions of what they get and what they give up in mobile services. Further, previous studies have pointed out that the key factors of mobile companies' success are the enhancement of perceived value and customer satisfaction (Yang and Peterson, 2004). Likewise, service perceived value is acknowledged in the literature as an antecedent which positively influences user satisfaction (Turel and Serenko, 2006).

Customer loyalty in mobile communication services is quite relevant because mobile communication services have the characteristics of typical contract services, in which most subscribers sign contracts over a specific period length to service providers (Kim et al., 2018).

Loyalty could be conceptualized as a deep commitment to rebuy or repatronize a preferred product or service consistently in the future (Oliver, 1999). Similarly, Dwivedi et al. (2017) report that the loyalty variable examines the repeated use of the same service over time. According to Gerpott et al. (2001), loyalty in the telecommunication mobile services industry is defined as a continuation of a business relationship between a service provider and a customer, leading to subsequent purchases, a contract extension or the customer intention to make future purchases from the service provider. Likewise, customer loyalty in the mobile sector could be defined as the intention of repurchase or remain consuming the service provided by the same service operator (Ruiz-Díaz, 2017). Therefore, in the present study, we assume the customer loyalty as the individual behavioral intention to continuously use mobile communication services with the current service providers. Moreover, previous research reports that perceived value influences customer loyalty in mobile services (Hsiao and Chen, 2016). Consequently, when users perceive that the value they obtain from a mobile service provider is high, they are more willing to engage with this company (Deng et al., 2010) and to remain loyal (Sirdeshmukh et al., 2002). Thus, we propose that when customers perceive a high service value, they will have an increased satisfaction; which in turn, will lead to a greater loyalty. Accordingly, the following research hypotheses are posed:

\section{H1. The mobile service perceived value has a positive influence on satisfaction}

H2. The mobile service perceived value has a positive influence on loyalty

2.1.2 The mobile service quality. According to Shin and Kim (2008), service quality is defined as the consumer or users' overall impression of the relative efficiency of a service provider. More precisely, previous studies report the quality of the network connection, a good value for money and the customer services as the main drivers influencing the user perceived quality (Gerpott et al., 2001). The mobile service quality indicates that the service used by the customers is delivered by the providers with a high level of security and privacy, practicality, enjoyment and sociality (Arcand et al., 2017). Further, a great number of studies integrate the mobile service quality measurement model developed by Kim et al. (2004) and Choi et al. (2008) which includes six dimensions of mobile service quality, namely, network quality, value-added 
services, mobile devices, customer services, pricing structure and billing system. Other authors reported as relevant factors of poor service quality the frequent disconnection or the lack of access (Shin, 2010). Finally, Deng et al. (2010) highlighted as the main variables influencing the perceived quality of mobile communication services the pricing policy, the network quality, the entertainment offer, the billing system and the customer service. Finally, and considering that ubiquity is one core attribute of mobile services, customers consider whether a specific mobile service is capable of providing consistent high-quality context-specific contents at different times and locations when evaluating the quality of mobile services (Wang et al., 2019). Therefore, mobile service providers are quite dependent on their capability to offer time- and location-specific services to meet their customer needs anytime and anywhere (Wang et al., 2019).

Previous research supports service quality as a driver of user satisfaction in the mobile services industry (Shin and Kim, 2008; Deng et al., 2010; Lu et al., 2011; Gao et al., 2015; Wang et al., 2019). Consequently, we propose that when users perceive high service quality, they will have an increased satisfaction. Similarly, several studies find a close relationship between the service quality and customer loyalty to a particular company or mobile service provider (Achour et al., 2011). Therefore, the following research hypotheses are posed:

H3. The mobile service quality has a positive influence on satisfaction.

H4. The mobile service quality has a positive influence on loyalty.

2.1.3 The mobile service provider corporate image. Corporate image can be defined as the set of meanings that individuals assign to a company and are used by them to remember, describe and relate to it as a result of their experiences, impressions, beliefs and feelings (Copley, 2004). Similarly, according to Aydin and Özer (2005), the corporate image is a result of an evaluation process, as it stems from all the consumption and usage experiences retrieved from memory and transformed into images. Following Nesset et al. (2011), corporate image is conceptualized as the way a company is defined in the individual's mind. Accordingly, in the present study, we assume that corporate image stems from all the customer's consumption experiences.

Previous studies have remarked the key role of corporate image in the way customers form their perceptions about the service providers' performance (Deng et al., 2010). So, when the users' perceptions of any service company are strongly related to attributes such as integrity and the company experience, being crucial for building and maintaining long-term customer relationships. The reason is that when users perceive that a mobile services company is reliable, trustworthy and with wide experience, they feel more satisfied (Deng et al., 2010). Accordingly, the corporate image is a determinant of user satisfaction (Nesset et al., 2011). Further, Srivastava and Sharma (2013) showed that corporate image is positively related to users' loyalty and repurchase intention in mobile services. Consequently, the following hypotheses are posed:

H5. The mobile company corporate image has a positive influence on satisfaction.

H6. The mobile company corporate image has a positive influence on loyalty.

\subsection{The moderating role of consumer involvement with information and communication technologies}

2.2.1 The influence of involvement in consumer evaluations. Petty and Cacioppo (1981) developed the elaboration likelihood model, which describes how consumers make
ICTs in mobile

(C)

\section{services}

29


SJME

23,1

evaluations in both low- and high-involvement circumstances, including the analysis of attitude formation. The elaboration likelihood model (Petty and Cacioppo, 1981) proposes that the degree to which individuals develop cognitive effort in evaluating a good or service depends on their level of involvement. More precisely, individuals follow either a peripheral or a central route to process information according to their level of involvement. Central route of information processing takes place under conditions of high involvement, such that consumers' responses to the product or service result from actively processing information. Therefore, the central route deals with the attitude formation based on thought, diligent and rational consideration of the product and service. However, in the peripheral route, individuals are unmotivated or unable to actively process information, such as productrelevant attributes; in turn, individuals will rely on peripheral, simple cues like the attractiveness of the source or some simple arguments when evaluating the good or service. Therefore, the peripheral route involves much less thought.

2.2.2 The concept of involvement. In his seminal work, Bloch (1982) defines involvement as an internal state reflecting the amount of interest or attention a consumer directs toward a product. Similarly, involvement can be considered a key determinant of consumer behavior, as it is characterized by stability and the resistance to the external influences (Thomsen et al., 1995).

Likewise, Beatty et al. (1988) described product involvement as the ongoing concern and feelings of interest, excitement, motivation and enthusiasm that consumers have about a specific product category. Much of the involvement definitional concern relates to whether involvement is object- or subject-oriented (Beatty et al., 1988). These authors conceptualized ego involvement as the importance of the product to the individual and the individual's values, being similar to a subject-oriented type of involvement. Similarly, authors like Lesschaeve and Bruwer (2010) conceptualized the enduring involvement as being related to the general personal relevance or interest of a product category to the individual. Consequently, in the present study, we will examine the different levels of consumer or user involvement, related to a subject-oriented involvement, which could be described as the importance of the product - ICTs - to the individual.

Consequently, the level of involvement could be classified as ranging from low to high involvement based on the degree of effort that an individual devotes to a product/ service category, related to the time invested in the choice and purchase decision and to the amount of information search or the time spent in evaluating alternatives (Zaichkowsky, 1986). Similarly, consumers with high product involvement have greater interest in product information, compare product attributes, hold more favorable beliefs about the product features and show higher purchase intention (Lesschaeve and Bruwer, 2010). Thus, highly involved consumers will invest time and effort to make the purchase decision.

Regarding the technology, Eagly and Chaiken (1993) suggested that involvement includes behavioral, emotional and cognitive components: the behavioral component is related to the familiarity and intensity of use of technologies; the emotional component covers feelings like enthusiasm or arousal; and the cognitive component includes knowledge and interest in the functionality of technologies. One related concept with ICT involvement is technophilia, which could be defined as the individual openness, interest and fascination toward ICTs (Rogers, 2003). Therefore, we can state that technophiles are individuals who are highly involved in technology.

Accordingly, the construct of involvement creates great interest in explaining differences between customers in their behavior in the mobile services industry. In the present study, we will conceptualize ICT involvement as the degree to which an individual is involved with technologies, likes and looks forward to learn about 
technologies. Therefore, when the consumer is highly involved in ICT, we assume that he/she finds technologies interesting and arousing and occupies his/her thoughts without a purchase objective.

2.2.3 The moderating role of the level of consumer involvement with information and communication technologies. The role of consumer involvement as a potential moderator variable in mobile services can be justified by the theory of attitude formation (Jones, 1970) and on the heuristic-systematic information processing model (Chaiken, 1980). Based on these two theories, Trumbo (1999) demonstrates that highly involved individuals use a systematic ICTs in mobile services processing of information, and in turn, these individuals form more stable attitudes, which have stronger influence on behavior. Accordingly, in the systematic information processing, individuals exert a great effort searching and examining information, as well as elaborating their beliefs and perceptions of objects.

Further, the heuristic-systematic information processing model (Chaiken, 1980) is in line with Zaichkowsky (1986) who reported that highly involved individuals have greater product information, compare attributes and hold more favorable beliefs about the product features. Similarly, Richins and Bloch (1988) indicated that highly involved users spend more time thinking about the product category, have a greater knowledge about the product or service and develop more accurate expectations about the product/service performance. In addition, authors such as Meyers-Levy and Peracchio (1996) note that highly involved individuals are more motivated to process available information more fully and diligently, whereas the less involved individuals are likely to use simple heuristics. Therefore, based on the heuristic-systematic information processing model (Chaiken, 1980), we propose that compared to less involved individuals, the more involved users will exert more effort in the mobile services selection process and, consequently, will have greater information about mobile communication services and about the service providers. Therefore, it can be assumed that highly involved ICT users will form more detailed service perceptions, influencing their purchase behavior, satisfaction and loyalty.

Regarding ICTs, Edison and Geissler (2003) suggest that highly involved individuals are more interested in ICTs and are more familiar with the everyday use of personal computers, mobile devices and communication technologies. Therefore, we can assume that consumers highly involved with ICTs would have greater knowledge and be better informed about technologies and their characteristics and would also develop higher loyalty.

Considering that involvement can lead to perceived differences in service outcome evaluations, we will examine the effect of varying involvement levels in the mobile services' context. However, we will not examine the potential moderating role of user involvement on the relationships of variables on satisfaction, as both highly and poorly involved consumers/users can enjoy greater levels of satisfaction (Richins and Bloch, 1988). More specifically, this study examines whether the level of consumer involvement with ICT may affect customer loyalty toward mobile service providers and thus, play a moderating role in loyalty in a technology-based service setting. According to Barnes et al. (2019), the user involvement with technology has a great explanatory power in usage behavior, being a powerful determinant of engagement and loyalty (So et al., 2016). Similarly, the user psychological involvement is closely related to attitudinal loyalty (Chaudhuri and Holbrook, 2001). Further, Espejel et al. (2009) report that the consumer involvement multiplies the influence of perceived quality on the level of consumer loyalty, thus exerting a moderating role. Therefore, we propose the level of consumer involvement with ICTs as a potential 
SJME

23,1

\section{2}

Figure 1.

Conceptual proposed model for the role of consumer involvement with ICTs moderating variable in the creation of loyalty toward mobile service providers (Figure 1). Thus, the following hypotheses are posed:

H7. The level of consumer involvement with ICTs moderates the influence of perceived value on loyalty to mobile services.

H8. The level of consumer involvement with ICTs moderates the influence of service quality on loyalty to mobile services.

H9. The level of consumer involvement with ICTs moderates the influence of corporate image on loyalty to mobile services.

\section{Methodology}

\subsection{Data collection}

The data for the study were collected by a self-administered structured online questionnaire among users residing in Spain in March 2015. The empirical study was conducted in Spain, given that it represents a mature European market where mobile devices have been widely adopted, presenting a large number of mobile device users. Further, mobile communication services show a high penetration rate in Spain, reaching a 122 per cent rate in year 2016 (European Commission, 2016) which makes it possible the generalization of the results to other developed economies.

Potential respondents were contacted by e-mail to participate in the study. Then, we proceeded with a random sampling among consumers, inviting them to complete the online questionnaire, and asking them about their mobile service providers, to gather information regarding the specific company they have knowledge or usage experience. Thus, each one of the participants evaluated their own mobile services company. Finally, this procedure yielded a total of 541 completed questionnaires, and a total amount of 493 valid responses were obtained comprising several mobile service companies operating in Spain such as Movistar, Vodafone, Orange, Pepephone, Simyo, Yoigo, Yazztel, R and Eroskimovil.

Similarly, and to examine the moderating role of the level of involvement with ICTs, the participants' level of involvement with ICTs was obtained using an involvement scale that contained three items regarding the individual's overall interest with technology: "technology is important to me", "I have a strong interest in technology" and "technology matters for me". The responses were measured using a five-point Likert-type scale, and for

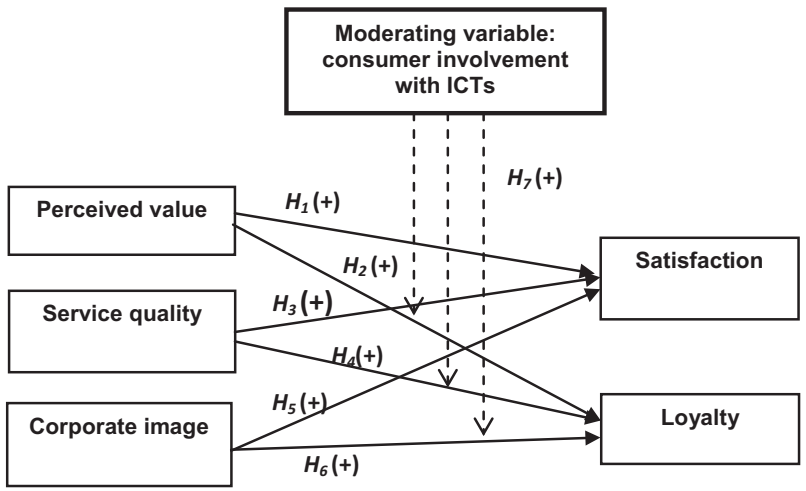


each participant, the involvement level was calculated by adding all the scores for each item. Accordingly, the total sample was divided into two sub-samples according to the level of involvement. Consequently, participants were classified as high involved consumers $(n=275)$ or low involved consumers $(n=218)$. Finally, the moderating influence of involvement will be examined through the Chi-Square comparison between the two groups.

The sampling error was 4.50 per cent, with a confidence level of 95 per cent and the last part of the questionnaire gathered the socio-demographic characteristics of the sample. Regarding the research sample profile, a total of 48.6 per cent of the participants were male, while the other 51.4 per cent of participants were female among highly involved customers; while the 62.6 per cent of participants were female and the other 37.4 per cent were male among the low involved customers.

In addition, the 38.1 per cent of the highly involved participants and the 36.7 per cent of the low involved participants were between 31 and 40 years old. In terms of education level, the 40.2 per cent of the highly involved and the 50.9 per cent of the low involved participants have university studies. Most of the participants are Movistar subscribers: 32.3 per cent among low involved participants and 30.6 per cent among highly involved participants (Table I).

\subsection{Variables and measurement scales}

All of the constructs in the conceptual model were measured using a multiple-item measurement scale, and all measures used a five-point Likert-type scale, with strongly disagree and strongly agree as the anchors. The measurement items were developed using a review of the literature related to our study (Table II). The service perceived value is measured by three items adopted from Kuo et al. (2009) to assess the overall perceived value. Second, the service quality was measured by three items adopted from Kuo et al. (2009). Third, we used three items to measure the corporate image, adopted from previous studies (Nguyen and LeBlanc, 2001). Regarding the variable customer satisfaction, we considered four items proposed by Burnham et al. (2003) and Kuo et al. (2009). Additionally, to measure customers' loyalty, we adopted three items from Yoo et al. (2000).

\section{Results}

\subsection{Analysis of the measurement model}

To examine the measurement model, we develop a confirmatory factor analysis. The first analysis revealed the need to remove the item QAL2 from the proposed initial scale, as the squared multiple correlations did not reach the commonly accepted threshold of 0.50 (Hair et al., 1998). Having removed this indicator, the results showed an appropriate specification of the proposed factorial structure. In relation with the analyses of the internal consistency and reliability, Cronbach's alpha $(\alpha)$, composite reliability (CR) coefficients and analysis of the average variance extracted (AVE) were calculated (Anderson and Gerbing, 1988). The confirmatory factorial analysis shows that all standardized factor loadings are significant, with a reliability level of 95 per cent and reaching the commonly accepted threshold of 0.60 (Hair et al., 1998). Regarding the internal consistency and reliability, Cronbach's alpha, CR coefficients and analysis of the average variance extracted (AVE) were calculated. In the first place, we obtained Cronbach's alpha values $(\alpha)$ from 0.797 to 0.922 , thus being acceptable (Hair et al., 1998). The CR of the latent variables was higher than 0.60 , indicating that all measures had good reliability (Hair et al., 1998). Additionally, the average variance extracted (AVE) varied from 0.652 to 0.836 , thus reaching the threshold of 0.50 ; meaning that a good
ICTs in mobile services 


\begin{tabular}{|c|c|c|c|c|c|}
\hline \multirow[b]{2}{*}{ Variable } & \multirow[b]{2}{*}{ Category } & \multicolumn{2}{|c|}{$\begin{array}{l}\text { High ICT involved } \\
\text { customers } \\
(n=275)\end{array}$} & \multicolumn{2}{|c|}{$\begin{array}{l}\text { Low ICT involved } \\
\text { customers } \\
(n=218)\end{array}$} \\
\hline & & Frequency & $(\%)$ & Frequency & $(\%)$ \\
\hline \multirow{6}{*}{ Age } & Younger than 20 years & 29 & 10.4 & 19 & 8.7 \\
\hline & $21-30$ & 77 & 28.0 & 67 & 30.5 \\
\hline & $31-40$ & 105 & 38.1 & 80 & 36.7 \\
\hline & $41-50$ & 35 & 12.9 & 27 & 12.6 \\
\hline & $51-60$ & 29 & 10.6 & 25 & 11.5 \\
\hline & Total & 275 & 100.00 & 218 & 100.00 \\
\hline \multirow{3}{*}{ Gender } & Male & 134 & 48.6 & 81 & 37.4 \\
\hline & Female & 141 & 51.4 & 137 & 62.6 \\
\hline & Total & 275 & 100.00 & 218 & 100.00 \\
\hline \multirow[t]{7}{*}{ Income (Euros/Year) } & $12.001-18.000$ & 13 & 4.6 & 25 & 11.3 \\
\hline & $18.001-24.000$ & 55 & 20.1 & 54 & 24.8 \\
\hline & $24.001-30.000$ & 82 & 29.7 & 51 & 23.5 \\
\hline & $30.001-36.000$ & 65 & 23.4 & 57 & 26.1 \\
\hline & $36.001-42.000$ & 44 & 16.1 & 23 & 10.7 \\
\hline & $>42.000$ & 16 & 5.8 & 8 & 3.6 \\
\hline & Total & 275 & 100.00 & 218 & 100.00 \\
\hline \multirow[t]{5}{*}{ Educational level } & Primary education & 50 & 18.0 & 22 & 10.1 \\
\hline & Secondary education & 109 & 39.5 & 80 & 36.9 \\
\hline & University education & 110 & 40.2 & 111 & 50.9 \\
\hline & Doctorate (PhD) & 6 & 2.3 & 5 & 2.1 \\
\hline & Total & 275 & 100.00 & 218 & 100.00 \\
\hline \multirow{10}{*}{ Mobile service operator } & Movistar & 84 & 30.6 & 70 & 32.3 \\
\hline & Vodafone & 61 & 22.1 & 63 & 28.9 \\
\hline & Orange & 38 & 13.8 & 26 & 11.8 \\
\hline & Yoigo & 32 & 11.6 & 10 & 4.6 \\
\hline & Pepephone & 10 & 3.7 & 11 & 4.5 \\
\hline & Simyo & 3 & 1.2 & 3 & 1.6 \\
\hline & Yazztel & 14 & 5.1 & 13 & 6.0 \\
\hline & $\mathrm{R}$ & 23 & 8.3 & 17 & 7.8 \\
\hline & Eroskimovil & 10 & 3.6 & 5 & 2.5 \\
\hline & Total & 275 & 100.00 & 218 & 100.00 \\
\hline
\end{tabular}

Table I.

convergent validity was obtained (Steenkamp and Van Trijp, 1991), as shown in Table III.

In addition, the measurement model was also examined. Results showed an adequate fit of the structural equation model, considering the goodness of fit indexes values: $\chi^{2}=243.170 ; \mathrm{df}=79 ; p<0.00 ; \mathrm{GFI}=0.890 ; \mathrm{NFI}=0.963 ; \mathrm{TLI}=0.967$ RMSEA $=0.050$; $\mathrm{RMR}=0.055 ; \mathrm{CFI}=0.973$ ). Then, discriminant validity was tested by evaluating all possible paired combinations of the constructs (Table IV). Results show that the AVE values were greater than the squared correlations between any pair of constructs, suggesting discriminant validity (Fornell and Larcker, 1981).

\subsection{Analysis of the structural model}

Structural equation modeling was developed to assess the statistical significance of the research hypotheses (Table V). Model fit criteria suggested by Hu and Bentler (1999) were used for both the measurement and the structural model: Acceptable models should have $\chi^{2} / \mathrm{df} \leq 3$, adjusted goodness of fit $(\mathrm{AGFI}) \geq 0.80$, root mean square residual (RMR) $\leq 0.1$, 


\begin{tabular}{l} 
Constructs \\
\hline Perceived value \\
Kuo et al. (2009) \\
Service quality \\
Kuo et al. (2009) \\
Corporate image \\
Nguyen and LeBlanc (2001) \\
Customer satisfaction \\
Burnham et al. (2003), Kuo \\
et al. (2009)
\end{tabular}

Loyalty

Yoo et al. (2000)
Indicators

PV1: My mobile services' company has successfully provided value-added services

PV2: Contracting mobile services of this company was a good decision

PV3: This mobile services' company provides me with many benefits

QAL1: My mobile company offers high quality services

QAL2: My mobile company provides services with good value for money

QAL3: My mobile company covers my needs perfectly

CI1: This company has a good image among consumers

CI2: I have a better image of my mobile services company, rather than other competing companies

CI3: I have a good image and associations of my mobile services company

SAT1: I am highly satisfied with the services provided by my mobile services' company

SAT2: So far, my mobile company has satisfied my expectations

SAT3: The decision to contract my mobile services' company was a good decision

LOY1: I will continue my subscription to my company

LOY2: Although there are other mobile providers available, I would continue my subscription with my company
ICTs in mobile services

35

Table II.

Measurement scale, variables and indicators

\begin{tabular}{|c|c|c|c|c|c|c|c|c|c|}
\hline \multirow[b]{2}{*}{ Constructs } & \multirow[b]{2}{*}{ Items } & \multirow{2}{*}{$\begin{array}{l}\text { Cronbach's } \\
\text { alpha }(\alpha)\end{array}$} & \multicolumn{3}{|c|}{$\begin{array}{c}\text { High ICT } \\
\text { involved customers }\end{array}$} & \multicolumn{3}{|c|}{$\begin{array}{c}\text { Low ICT } \\
\text { involved customers }\end{array}$} & \\
\hline & & & Lambda $(\lambda)$ & $\mathrm{CR}$ & AVE & Lambda $(\lambda)$ & $\mathrm{CR}$ & AVE & \\
\hline Perceived value & PV1 & 0.874 & 0.795 & 0.914 & 0.782 & 0.691 & 0.847 & 0.652 & \\
\hline & PV3 & & $\begin{array}{l}0.933 \\
0.917\end{array}$ & & & $\begin{array}{l}0.922 \\
0.792\end{array}$ & & & \\
\hline Service quality & QAL1 & 0.907 & 0.918 & 0.909 & 0.836 & 0.811 & 0.810 & 0.682 & \\
\hline Corporate image & $\begin{array}{l}\text { QAL3 } \\
\text { CI1 }\end{array}$ & 0.872 & $\begin{array}{l}0.908 \\
0.784\end{array}$ & 0894 & 0738 & $\begin{array}{l}0.840 \\
0.733\end{array}$ & 0842 & 0641 & \\
\hline Corporate image & $\mathrm{CI} 2$ & 0.812 & 0.873 & 0.894 & 0.738 & 0.777 & $0.84 Z$ & 0.041 & \\
\hline Satisfaction & $\begin{array}{l}\mathrm{CI} 3 \\
\mathrm{SAT} 1\end{array}$ & 0.922 & $\begin{array}{l}0.934 \\
0.899\end{array}$ & 0.933 & 0831 & 0.884 & 0867 & 0685 & Table III. \\
\hline satisfaction & $\begin{array}{l}\text { SA11 } \\
\text { SAT2 } \\
\text { SAT3 }\end{array}$ & 0.922 & $\begin{array}{l}0.099 \\
0.871\end{array}$ & 0.900 & 0.054 & $\begin{array}{l}0.808 \\
0.833 \\
0.842\end{array}$ & 0.001 & 0.000 & $\begin{array}{r}\text { Factor loadings and } \\
\text { indicators of }\end{array}$ \\
\hline Loyalty & $\begin{array}{l}\text { LOY1 } \\
\text { LOY2 }\end{array}$ & 0.797 & $\begin{array}{l}0.924 \\
0.690\end{array}$ & 0.807 & 0.681 & $\begin{array}{l}0.042 \\
0.792 \\
0.692\end{array}$ & 0.733 & 0.539 & $\begin{array}{l}\text { consistency and } \\
\text { reliability }\end{array}$ \\
\hline
\end{tabular}

root mean square error of approximation (RMSEA) $\leq 1.0$ and GFI and comparative fit index (CFI) higher than 0.90. All the model fit indices exceeded the respective common acceptance levels, indicating that the measurement model exhibited a good fit of the collected data.

\subsection{Analysis of the relationships among variables}

Structural equation modeling was used to test the hypothesized relationships, via the maximum likelihood estimator using software Amos 18.0. Our findings support the proposed conceptual model, as only two out of the seven of the proposed relationships were 
SJME

23,1

\section{6}

Table IV.

Correlations among constructs not identified (Table VI). Likewise, the obtained results highlight that the level of involvement with ICTs, namely, highly and poorly involved in ICT consumers, reported interesting differences in terms of the variables influencing the creation of satisfaction and loyalty towards the mobile services.

The results obtained indicate that service quality is the dimension with higher loading on customer satisfaction $\left(\beta_{24 \mathrm{H}}=0.437^{* *} ; \beta_{24 \mathrm{~L}}=0.225^{* *}\right)$, followed by perceived value $\left(\beta_{14 \mathrm{H}}=\right.$ $\left.0.287^{* * *} ; \beta_{14 \mathrm{~L}}=0.237^{* * *}\right)$. Therefore, in terms of the effect size, the mobile communication service perceived quality seems to contribute the most to customer satisfaction. Therefore, it can be stated that the better mobile service quality and the greater perceived value, the higher satisfaction regardless the level of involvement with ICTs. Additionally, we found empirical evidence to propose a significant positive relationship between corporate image and user satisfaction $\left(\beta_{34 \mathrm{H}}=0.305^{* * *}\right)$ for highly ICT involved consumers; but this relationship did not reach statistical significance for low ICT involved users $\left(\beta_{34 \mathrm{~L}}=0.136^{\mathrm{ns}}\right)$. One potential explanation would be that low or poorly involved users do not have a clear image or associations regarding mobile service companies, because of their lower knowledge and information.

Regarding the factors influencing loyalty towards mobile service providers we should highlight that only one of the proposed relationships - perceived value - is significantly positive for users with high ICT involvement $\left(\beta_{15 \mathrm{H}}=0.194^{* * *}\right)$. Nevertheless, the other variables under analysis, namely, the service quality $\left(\beta_{25 \mathrm{H}}=0.013^{\mathrm{ns}}\right)$ and corporate image $\left(\beta_{35 \mathrm{H}}=0.008^{\mathrm{ns}}\right)$, showed no significant influence on loyalty, contrary to our initial expectations, as the relationships were in the expected direction, but failed to reach statistical significance. Therefore, our findings do not empirically support a significant relationship between service quality and loyalty, as well as between corporate image and loyalty.

One possible explanation may be that users highly involved with ICT have great information about the technology-based services provided and seek for greater quality,

\begin{tabular}{lcccccccccc}
\hline & \multicolumn{4}{c}{ High ICT involved customers } & \multicolumn{5}{c}{ Low ICT involved customers } \\
& PV & SQ & CI & sat & LOY & pv & sq & ci & sat & loy \\
\hline Perceived value & 0.782 & & & & & 0.652 & & & & \\
Service quality & 0.618 & 0.836 & & & & 0.600 & 0.682 & & & \\
Corporate image & 0.512 & 0.634 & 0.738 & & & 0.618 & 0.634 & 0.641 & & \\
Satisfaction & 0.705 & 0.715 & 0.667 & 0.834 & & 0.602 & 0.613 & 0.606 & 0.685 & \\
Loyalty & 0.709 & 0.663 & 0.669 & 0.627 & 0.681 & 0.509 & 0.550 & 0.504 & 0.521 & 0.539
\end{tabular}

Note: The diagonal values in bold represent the square root of the average variance extracted of each construct

\begin{tabular}{|c|c|c|c|c|c|c|c|c|c|c|c|}
\hline \multirow[b]{2}{*}{ Chi-square } & \multicolumn{5}{|c|}{ Absolute fit measures } & \multicolumn{5}{|c|}{ Incremental fit measures } & \multirow{2}{*}{$\begin{array}{c}\text { Parsimony } \\
\text { measures } \\
\text { Normed } \\
\text { Chi-square }\end{array}$} \\
\hline & df & $\mathrm{p}$ & GFI & RMSEA & RMR & AGFI & NFI & IFI & TLI & $\mathrm{CFI}$ & \\
\hline 299.170 & 108 & 0.000 & 0.899 & 0.070 & 0.060 & 0.823 & 0.929 & 0.953 & 0.932 & 0.953 & 2.770 \\
\hline
\end{tabular}




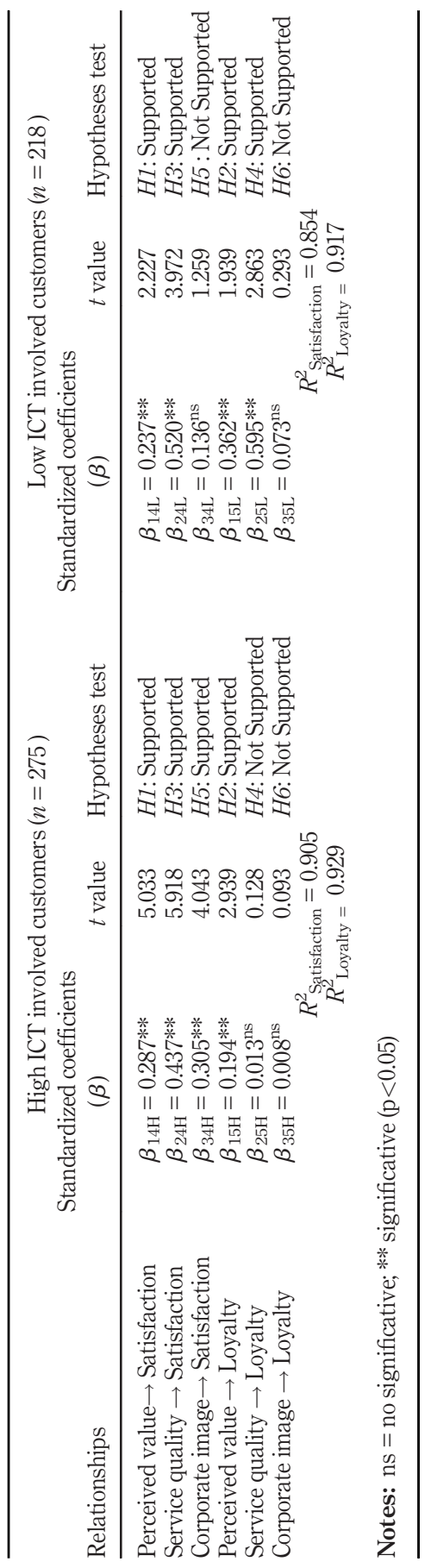

ICTs in mobile services and test of research hypotheses 
SJME

23,1

38

regardless the specific company offering them; and in turn, highly involved users are more difficult to retain. Likewise, our results highlight a significant direct relationship between mobile communication service quality and loyalty $\left(\beta_{25 \mathrm{~L}}=0.595^{* * *}\right)$, as well as between service perceived value and loyalty $\left(\beta_{15 \mathrm{~L}}=0.362^{* * *}\right)$ for consumers with low involvement with ICTs. However, we did not find empirical support for a significant relationship between corporate image and loyalty $\left(\beta_{35 \mathrm{~L}}=0.073^{\mathrm{ns}}\right)$, contrary to our initial expectations. Therefore, it seems that the mobile service provider image does not have an impact on loyalty, despite the level of service quality provided or the type of services offered.

Finally, our results provide support for most of the proposed research hypotheses for highly involved consumers - H1, H2, $H 3$ and $H 5$ - thus not supporting $H 4$ and $H 6$. Similarly, our findings support $\mathrm{H1}, \mathrm{H} 2, \mathrm{H} 3$ and $\mathrm{H} 4$ for low involved consumers, while not providing empirical support for $\mathrm{H} 5$ and $\mathrm{H} 6$.

\subsection{The moderating role of involvement with information and communication technologies}

To examine the hypothesis that consumers' involvement with ICTs moderates the influence of perceived value, service quality and corporate image on loyalty towards mobile service providers, a structural equation model was tested through a multiple-group analysis. More precisely, the research sample was divided into two sub-samples, according to the consumers' level of involvement with ICTs. Therefore, sample comparisons were then made between highly ICT involved consumers $(n=275)$ and those who showed a low ICT involvement $(n=218)$.

In the first place, the conceptual proposed model was estimated with all hypothesized parameters allowed to be estimated freely within each sub-sample $\left(\chi^{2}=299.170 ; p<0.000\right.$; $\mathrm{CFI}=0.953)$. Then, in a series of constrained models, the path coefficients corresponding to the links between perceived value-loyalty (H7), service quality-loyalty (H8) and corporate image-loyalty $(H 8)$ were constrained to remain invariant.

Prior research on the examination of the moderating role considers the increase of the value of the Chi-Square distribution (Perez and Garcia, 2012; Fernández-Sabiote $e$ t al., 2013). Our findings show that the significantly higher $\chi^{2}$ values for the constrained models did not improve the model fit in one out of three of the proposed relationships (Table VII). Therefore, these results support the hypothesized moderating role of the customer involvement with ICTs on the service quality-loyalty link $\left(\Delta \chi^{2}=4.867\right.$; $\left.\mathrm{df}=1, p<0.000\right)$. However, the no significant values for the increase of $\mathrm{X}^{2}$, do not support the moderating influence of involvement with ICTs in the perceived value-loyalty link $\left(\Delta \chi^{2}=0.867 ; \mathrm{df}=1, p<0.000\right)$ and in the corporate image-loyalty $\operatorname{link}\left(\Delta \chi^{2}=0.052 ; \mathrm{df}=1, p<0.000\right)$.

\section{Conclusions}

The present study aims to contribute to the existing literature in the field user involvement by examining the moderating role of the level of consumer involvement with ICTs, and its

Table VII.

Analysis of the moderating role of customer involvement with IC technologies

\begin{tabular}{lccccc}
\hline Moderating effect & Chi-square & df & & \multicolumn{2}{c}{ CFI } \\
\hline Unconstrained baseline model & 299.170 & 108 & & & 0.953 \\
& & & & & \\
Constrained paths & Chi-square & $\Delta X^{2}$ & df & $p$ & Hypotheses \\
Perceived value $\rightarrow$ Loyalty & 300.236 & 0.867 & 109 & 0.000 & H71:Not Supported \\
Service quality $\rightarrow$ Loyalty & 304.037 & 4.867 & 109 & 0.000 & H72: Supported \\
Corporate image $\rightarrow$ Loyalty & 299.222 & 0.052 & 109 & 0.000 & H73: Not Supported \\
All path constraint & 304.410 & 5.24 & 111 & 0.000 & \\
\hline
\end{tabular}


potential influence in the mobile service behavior, since service outcome evaluations are influenced by the level of consumer involvement.

Our conceptual proposed model was supported by the data collected, describing some

ICTs in mobile empirical findings of the factors that determine user satisfaction and loyalty with mobile communication services, comparing different levels of consumer involvement with ICTs.

This study aimed to examine whether the level of involvement with ICTs influences or not the consumer behavior in the mobile services industry. Our findings report that the level of consumer involvement with ICTs plays a moderating role in the creation of customer loyalty with mobile service providers. More precisely, our findings support a partial moderating role of consumers' involvement with ICTs, highlighting that consumers slightly involved with ICTs experience a greater impact of the service quality on their loyalty to the mobile service providers. One potential explanation is that poorly involved ICT users rely on their subjective quality perception or on service attributes to a greater extent, being in line with Petty and Cacioppo (1981). Another potential reason is that user involvement with ICTs might be playing a mediating role, between service quality, perceived value, corporate image and loyalty.

Likewise, the present research analyzes the factors that drive user satisfaction and loyalty in the mobile services industry. Our findings highlight that service quality, followed by the service perceived value are the main factors influencing customer satisfaction and loyalty, while the company corporate image has less explanatory power, regardless the level of consumer involvement with ICTs. Therefore, in line with previous studies in the mobile sector, both service quality (Lu et al., 2011; Gao et al., 2015; Wang et al., 2019) and perceived service value (Yang and Peterson, 2004; Turel and Serenko, 2006; Hsiao and Chen, 2016) were shown to be good predictors of customer satisfaction and loyalty.

In fact, one interesting finding is that the mobile services' quality is the driver with the largest effect on customer satisfaction followed by service perceived value, as proposed by Kuo et al. (2009). In addition, the corporate image showed a slight impact. One possible explanation for the low impact of corporate image is that this variable might be considered an outcome of satisfaction when corporate image is considered as "the total of what consumers think about a particular company" (Nesset et al., 2011).

Therefore, we can state that when mobile service providers reinforce their services' quality, customer satisfaction and loyalty are considerably improved. This result is in line with Kuo et al. (2009) and Wang et al. (2019) and implies that if mobile service companies aim to induce higher customer satisfaction, the enhancement of service quality should be prioritized.

Another relevant finding is the important influence of service quality and perceived value on user loyalty for low involved consumers. So that, the higher the mobile service quality and service perceived value, the higher customer loyalty, when consumers are slightly involved or interested in ICTs. Likewise, another interesting finding is that results do not provide empirical support for service quality and corporate image as exerting a significant influence on loyalty for highly involved ICTs consumers. One possible explanation is that these consumers have great information about the technology-based services provided, and seek for a greater service quality; thus being more difficult to retain. Moreover, our findings show the lack of significant influence of the service provider corporate image on loyalty, regardless the level of consumer involvement with ICTs.

The major contribution of the present study is the analysis of the moderating role of consumer involvement with ICTs in the behavior toward mobile services, reporting a partial moderating effect. We hypothesized the potentially moderating influence of consumer involvement, and our results confirm our initial hypotheses for the relationship between service quality and loyalty. 


\subsection{Managerial implications, limitations and future research guidance}

Derived from our findings, we propose some useful insights for mobile service providers. In the first place, service providers could develop market segmentation and perform marketing strategies based on the consumers' level of involvement with ICTs. Moreover, mobile tailored services could be offered to these specific groups of customers, based on their involvement with technologies. The highly involved customer segment is important from a manager's perspective, since these customers are heavy users of the product or service category. In this sector, many mobile service providers are concerned about building and maintaining long-term relationships with their customers, as attracting new customers is considered more expensive than retaining current ones. In this context, mobile providers could improve customers' satisfaction and loyalty through the reinforcement of service quality. Further, our findings suggest that mobile service companies should offer added value and personalized communication services as a way to enhance user satisfaction, such as customized applications, location-based services, interactive voice-response services, mobile money transfer or customized infotainment. Additionally, to improve the mobile services' perceived value, the service providers could give personal functional benefits or enhance the key functionalities of mobile services.

This research has several limitations which also provide possible avenues for future research. As for the main limitation of this study, our findings reflect consumer behavior referring to various mobile services; however, the research could have focused on a more specific mobile service such as voice service, mobile internet access, data service, locationbased service or other innovative mobile service. In the second place, this empirical research was carried out in one single market. In the third place, our study analyzed a number of variables proposed in previous literature, which only represent a small part of all factors affecting customer satisfaction with mobile communication services, such as trust in the company or the price level.

Furthermore, future research on the topic could examine the potential mediation role of consumer involvement with ICTs. In doing so, a comparison between the moderating and mediating role of involvement could be provided. Finally, the relationship between satisfaction and loyalty was not considered in the present research, and a moderating effect of consumer involvement with ICTs could also exist. Hence, although this study reports interesting results, caution must be exercised when generalizing results, and consequently, replicating this study in other contexts and countries could validate the findings reported.

\section{References}

Achour, M., Pujawati, N. and Boerhannoeddin, A. (2011), "Customer loyalty: the case of mobile phone user in university utara Malaysia”, International Journal of Management Studies, Vol. 18 No. 2 , pp. $43-66$.

Anderson, J.C. and Gerbing, D.W. (1988), "Structural equation modeling in practice: a review and recommended two step approach", Psychological Bulletin, Vol. 103 No. 3, pp. 411-423.

Arcand, M., PromTep, S., Brun, I. and Rajaobelina, L. (2017), "Mobile banking service quality and customer relationships", International Journal of Bank Marketing, Vol. 35 No. 7, pp. 1068-1089.

Aydin, S. and Özer, G. (2005), "The analysis of antecedents of customer loyalty in the turkish mobile telecommunication market”, European Journal of Marketing, Vol. 39 Nos 7/8, pp. 910-925.

Baabdullah, A.M., Alalwan, A.A. and Al Qadi, N.S. (2018), "Evaluating the current situation of mobile services in the kingdom of Saudi Arabia”, Emerging Markets from a Multidisciplinary Perspective, Vol. 2 (Springer), pp. 149-160. 
Barnes, S.J., Pressey, A.D. and Scornavacca, E. (2019), "Mobile ubiquity: understanding the relationship between cognitive absorption, smartphone addiction and social network services", Computers in Human Behavior, Vol. 90, pp. 246-258.

Beatty, S.E., Kahle, L.R. and Homer, P. (1988), "The involvement-commitment model: theory and mplications", Journal of Business Research, Vol. 16 No. 2, pp. 149-167.

Bloch, P.H. (1982), "Involvement beyond the purchase process: conceptual issues andi empirical nvestigation", in Mitchell, A. (Ed.), Advances in Consumer Research, Association for Consumer Research, Ann Arbor.

ICTs in mobile services

Burnham, T., Frels, J. and Mahajan, J.V. (2003), "Consumer switching costs: a typology, antecedents and consequences", Journal of the Academy of Marketing Science, Vol. 31 No. 2, pp. 109-126.

Chaiken, S. (1980), "Heuristic versus systematic information processing and the use of source versus message cues in persuasion”, Journal of Personality and Social Psychology, Vol. 41 No. 1, pp. 1-12.

Chaudhuri, A. and Holbrook, M.B. (2001), "The chain of effects from brand trust and brand affect to brand performance: the role of brand loyalty", Journal of Marketing, Vol. 65 No. 2, pp. 81-93.

Choi, J., Seol, L., Lee, S., Cho, H. and Park, Y. (2008), "Customer satisfaction factors of mobile commerce in korea?", Internet Research, Vol. 18 No. 3, pp. 313-335.

Comisión Nacional de los Mercados y la Competencia (CNMC) (2017), Informe Económico Sectorial de las Telecomunicaciones y el Audiovisual.

Copley, P. (2004), Marketing Communications Management: Concepts and Theories Cases and Practices, Elsevier, New York, NY.

Deng, Z., Lu, Y., Wei, K.K. and Zhang, J. (2010), "Understanding customer satisfaction and loyalty: an empirical study of mobile instant messages in China?", International Journal of Information Management, Vol. 30 No. 4, pp. 289-300.

Durndell, A. and Haag, Z. (2002), "Computer self-efficacy, computer anxiety, attitudes towards the internet and reported experience with the internet by gender in an east european sample", Computers in Human Behaviour, Vol. 18 No. 5, pp. 521-535.

Dwivedi, Y.K., Rana, N.P., Jeyaraj, A., Clement, M. and Williams, M.D. (2017), "Reexamining the unified theory of acceptance and use of technology (UTAUT): towards a revised theoretical model", Information Systems Frontiers, Vol. 2, pp. 1-16.

Eagly, A.H. and Chaiken, S. (1993), The Psychology of Attitudes, Fort Worth, Harcourt.

Edison, S. and Geissler, G. (2003), "Measuring attitudes towards general technology: antecedents, hypotheses and scale development", Journal of Targeting, Measurement and Analysis for Marketing, Vol. 12 No. 2, pp. 137-156.

Eshghi, A., Haughton, D. and Topi, H. (2007), "Determinants of customer loyalty in the wireless telecommunications industry", Telecommunications Policy, Vol. 31 No. 2, pp. 93-106.

Espejel, J., Fandos, C. and Flavián, C. (2009), "The influence of consumer involvement on quality signals perception: an empirical investigation in the food sector", British Food Journal, Vol. 111 No. 11, pp. 1212-1236.

European Commission (2016), Digital Economy and Society Report, Digital Agenda Key Indicators.

Fernández-Sabiote, E., Román, S. and Martín-Castejón, P.J. (2013), "The effect of social regard on the customer-service provider relationship and the moderating role of the type of service", Revista Española de Investigación de Marketing-ESIC, Vol. 17 No. 1, pp. 39-59.

Fornell, C. and Larcker, D.F. (1981), "Evaluating structural equation models with unobservable variables and measurement error", Journal of Marketing Research, Vol. 18 No. 1, pp. 39-50.

Gao, L., Waechter, K.A. and Bai, X. (2015), “Understanding consumers' continuance intention towards mobile purchase: a theoretical framework and empirical study - a case of China", Computers in Human Behavior, Vol. 53, pp. 249-262. 
Gerpott, T., Rams, W. and Schindler, A. (2001), "Customer retention, loyalty and satisfaction in the german mobile cellular telecommunications market”, Telecommunications Policy, Vol. 25 No. 4, pp. $249-269$.

Hair, J.F., Anderson, R.E., Tatham, R. and Black, W.C. (1998), Multivariate Data Analysis, Prentice-Hall, Upper Saddle River, NJ.

Hsiao, K.-L. and Chen, C.-C. (2016), "What drives in-app purchase intention for mobile games? An examination of perceived values and loyalty", Electronic Commerce Research and Applications, Vol. 16 No. 2, pp. 18-29.

Hu, L. and Bentler, M.P. (1999), "Cutoff criteria for fit indexes in covariance structure analysis: conventional criteria versus new alternatives", Structural Equation Modeling, Vol. 6 No. 1, pp. 1-55.

Im, S., Bhat, S. and Lee, Y. (2015), "Consumer perceptions of product creativity, coolness, value and attitude", Journal of Business Research, Vol. 68 No. 1, pp. 166-172.

International Telecommunication Union (2015), Policy and Market Analysis, World Summit of the Information Society.

Jones, J.F. (1970), "The theory of attitude formation and change and its application to social growup ork", United College Journal, pp. 21-28.

Kim, M.K., Park, M.C. and Jeong, D.H. (2004), "The effects of customer satisfaction and switching barrier on customer loyalty in korean mobile telecommunication services", Telecommunications Policy, Vol. 28 No. 2, pp. 145-159.

Kim, M.K., Park, M.C., Park, J.H., Kim, J. and Kim, E. (2018), "The role of multidimensional switching barriers on the cognitive and affective satisfaction-loyalty link in mobile communication services: coupling in moderating effects", Computers in Human Behavior, Vol. 87, pp. 212-223.

Kuo, Y.F., Wu, C.M. and Deng, W.J. (2009), “The relationships among service quality, perceived value, customer satisfaction and post-purchase intention in mobile value-added services", Computers in Human Behaviour, Vol. 25 No. 4, pp. 887-896.

Lesschaeve, I. and Bruwer, J. (2010), "The importance of involvement and implications for new product development", in Jaeger, S.R. and MacFie, H., (Eds), Consumer-Driven Innovation in Food and Personal Care Products, Woodhead Publishing Ltd., Cambridge, UK.

Li, M. and Mao, J. (2015), "Hedonic or utilitarian? Exploring the impact of communication style alignment on user's perception of virtual health advisory services", International Journal of Information Management, Vol. 35 No. 2, pp. 229-243.

Lu, T., Tu, R. and Jen, W. (2011), "The role of service value and switching barriers in an integrated model of behavioural intentions", Total Quality Management, Vol. 22 No. 10, pp. 1071-1089.

Meyers-Levy, J. and Peracchio, L.A. (1996), "Moderators of the impact of self-reference on persuasion", Journal of Consumer Research, Vol. 22 No. 4, pp. 408-423.

Nesset, E., Nervik, B. and Helgesen, Ø. (2011), "Satisfaction and image as mediators of store loyalty drivers in grocery retailing", The International Review of Retail, Distribution and Consumer Research, Vol. 21 No. 3, pp. 267-292.

Nguyen, N. and LeBlanc, G. (2001), “Corporate image and corporate reputation in customers' retention decisions in services", Journal of Retailing and Consumer Services, Vol. 8 No. 4, pp. 227-236.

Oliver, R.L. (1999), “Whence consumer loyalty?”, Journal of Marketing, Vol. 63 No. 4, pp. 33-44.

Perez, R.C. and Garcia, I.S. (2012), "Satisfacción y lealtad hacia un sitio web: el efecto moderador del riesgo percibido", ESIC Market, Vol. 141, pp. 209-234.

Petty, R.E. and Cacioppo, J.T. (1981), Attitudes and Persuasion: Classic and Contemporary Approaches, McGraw-Hill, New York, NY.

Richins, M.L. and Bloch, P.H. (1988), "The role of situational and enduring involvement in PostPurchase eproduct valuation", Journal of Consumer Satisfaction, Dissatisfaction and Complaining Behaviour, Vol. 1 No. 1, pp. 10-15. 
Rogers, E. (2003), Diffusion of Innovations, The Free Press, New York, NY.

Ruiz-Díaz, G. (2017), "The influence of satisfaction on customer retention in mobile phone market", Journal of Retailing and Customer Services, Vol. 36, pp. 75-85.

ICTs in mobile services

Shin, D.H. (2010), "MVNO services: policy implications for promoting MVNO diffusion", Telecommunications Policy, Vol. 34 No. 10, pp. 616-632.

Shin, D.H. and Kim, W.Y. (2008), "Forecasting customer switching intention in mobile service: an exploratory study of predictive factors in mobile number portability", Technological Forecasting and Social Change, Vol. 75 No. 6, pp. 854-874.

Sirdeshmukh, D., Singh, J. and Sabol, B. (2002), "Consumer trust, value, and loyalty in relational exchanges”, Journal of Marketing, Vol. 66 No. 1, pp. 15-37.

So, K.K., King, C., Sparks, B.A. and Wang, Y. (2016), "Enhancing customer relationships with retail service brands: the role of customer engagement", Journal of Services Management, Vol. 27 No. 2, pp. 170-193.

Srivastava, K. and Sharma, N.K. (2013), "Service quality, corporate brand image, and switching behavior: the mediating role of customer satisfaction and repurchase intention", Services Marketing Quarterly, Vol. 34 No. 4, pp. 274-291.

Steenkamp, E.M. and Van Trijp, C.M. (1991), "The use of LISREL in validating mcarketing onstructs", International Journal of Research in Marketing, Vol. 8 No. 4, pp. 283-299.

Sweeney, J.C. and Soutar, G.N. (2001), "Consumers perceived value: the development of a multiple item scale", Journal of Retailing, Vol. 77 No. 2, pp. 203-220.

Thomsen, C.J., Borgida, E. and Lavine, H. (1995), "The causes and consequences of personal involvement", in Petty, R.E. and Krosnick, J.A., Eds. Attitude Strength: Antecedents and Consequences, Erlbaum, Mahwah, NJ.

Trumbo, C.W. (1999), "Heuristic-systematic information processing and risk judgment", Risk Analysis, Vol. 19 No. 3, pp. 391-400.

Turel, O. and Serenko, A. (2006), "Satisfaction with mobile services in Canada: an empirical investigation”, Telecommunications Policy, Vol. 30 Nos 5/6, pp. 314-331.

Venkatesh, V., Thong, J. and Xu, X. (2012), "Consumer acceptance and use of information technology: extending the unified theory of acceptance and use of technology", MIS Quarterly, Vol. 36 No. 1, pp. 157-178.

Wang, W.T., Ou, W.M. and Chen, W.Y. (2019), "The impact of inertia and user satisfaction on the continuance intentions to use mobile communication applications: a mobile servicpe quality erspective", International Journal of Information Management, Vol. 44, pp. 178-193.

Yang, Z. and Peterson, R.T. (2004), "Customer perceived value, satisfaction, and loyalty: the role of switching costs", Psychology and Marketing, Vol. 21 No. 10, pp. 799-822.

Yoo, B., Donthu, N. and Lee, N.S. (2000), "An examination of selected marketing mix elements and Berand quity”, Journal of the Academy of Marketing Science, Vol. 28 No. 2, pp. 195-211.

Zaichkowsky, J.L. (1986), "Conceptualizing involvement”, Journal of Advertising, Vol. 15 No. 2, pp. 4-14.

Zhou, T. (2011), "An empirical examination of users' post-adoption behaviour of mobile services", Behaviour and Information Technology, Vol. 30 No. 2, pp. 241-250.

\section{Corresponding author}

Cristina Calvo-Porral can be contacted at: ccalvo@udc.es

For instructions on how to order reprints of this article, please visit our website:

www.emeraldgrouppublishing.com/licensing/reprints.htm

Or contact us for further details: permissions@emeraldinsight.com 